\title{
Quality of Human Resources Apparatus in Karimun Regency Riau Archipelagic Province
}

\author{
Kamarulazi, Khasan Effendy, Aries Djaenuri, Sampara Lukman, Indonesia \\ E-mail: lazzy250@gmail.com
}

Received: Aug. 19, 2018 Accepted: Sep. 4, 2018 Online published: Sep. 20, 2018

doi:10.5296/jpag.v8i3.13516ＵRL: https://doi.org/10.5296/jpag.v8i3.13516

\begin{abstract}
This paper examines the quality of the apparatus resources of Karimun District Government of Riau Islands Province. The problems that arise in Karimun Regency of Riau Islands Province are the quality in the application of Karimun Regency Government apparatus which still face the problems related to the implementation of regional autonomy. Thus, the quality and ability of human resources become things that need to be improved again. In addition, the working environment in Karimun regency of Riau Islands Province that demand competent ability to compete, but Karimun Regency Government apparatus resources still not optimal. The results showed that the Government of Karimun Regency of Riau Islands Province has had the quality of apparatus resources at Karimun Regency Government of Riau Islands Province supported by the implementation of duty by the employees. Specialization of employees in a particular field has become an amplifier of the quality of apparatus resources at the Government of Karimun District of Riau Islands Province. The loyalty of employees has been proven as a quality apparatus resources at the Government of Karimun District of Riau Islands Province.
\end{abstract}

Keywords: quality of apparatus resources, implementation of regional autonomy, Karimun district government of Riau islands province

\section{Introduction}

The smooth implementation of governance and national development depends mainly on the perfection of the state apparatus and the perfection of the Regional Government apparatus of Karimun Regency of Riau Islands Province depends essentially on the perfection of civil servants. The perfect civil servant is a loyal civil servant to the Pancasila, the 1945 Constitution and the government and united, well minded, disciplined, authoritative, efficient, high quality and aware of responsibility as the first element of the state apparatus. Drucker (1954:2) says "High discipline is one of the elements to become a perfect civil servant. High discipline is expected that all activities will run well". 
There are a number of problems faced by the regional government bureaucracy Karimun Riau Islands Province which is said by Riorini (2004:253-274) that low quality of regional civil servants, incompatibility of competence, placement error, obscurity career path that can be reached and to the discipline of civil servants.

Based on data from the Human Resources Agency and Human Resources Development of Karimun Regency, the number of civil servants in Karimun Regency Riau Islands Province in 2017 is 4,163 employees. From this number can be seen that the number of civil servants Karimun Regency Riau Islands Province is quite large. The quality of civil servants of the local government of Karimun Regency of Riau Islands Province is low caused by several things, namely the knowledge of civil servants on the problems of the field which is still not optimal so as not yet able to answer the needs of the public for high quality civil servants due to the placement of employees who are not in accordance with the discipline obtained. Another thing again with the lazy civil servants who came to office just to fill the attendance list then go home without carrying out the responsibilities that have been given.

A fact that occurs in everyday life about the bureaucracy of Karimun District Government of Riau Islands Province stated that they, Civil Servants Work area relaxed, go home quickly and complicate the affairs and identical with a term "why should be facilitated if complicated". The general description has been so embedded in the public mind in the Government of Karimun District of Riau Islands Province that many people assume that the difference between the thugs and the bureaucracy is only in official clothing.

The public's view of the Regional Civil Servant in Karimun Regency of Riau Islands Province is unsatisfactory, and some even reported the existence of the Civil Servant of the Region to perform poorly. These civil servants simply take their salary without contributing significantly to their work. Therefore, the Karimun District Government of Riau Islands Province has offered additional relocation and education.

The low quality of civil servants of Karimun District Government of Riau Islands Province is also caused by the low skill that is owned and can be seen that there are still many civil servants of Karimun District Government of Riau Islands Province who has not fully mastered the use of computer so that resulted in work which the work should be finished quickly even become slow due to lack of computer operating skills.

One indication of the low quality of civil servants Regional Government of Karimun Regency of Riau Islands Province which is said by Siagian (1997:32) that is a violation of discipline that many carried out by civil servants. The ongoing development in Karimun District Government of Riau Islands Province often encounters many obstacles and complex problems. It can cause disorder in the life of nation and state. Increased discipline within the local government apparatus of Karimun Regency of Riau Islands Province is one of the efforts to overcome the disorder.

The realization of Karimun Regency Government Riau Islands Province clean and authoritative begins with the enforcement of national discipline in the environment of the state apparatus, especially Civil Servant of Region and equality of Human Resource 
Employee of Regency Government of Karimun Regency of Riau Islands Province.

The change in attitude and the nature of the work is a change towards a knowledge-based work that requires a knowledgeable workforce as well, as simplicity and work routines have shifted towards innovative, multi-skilled work and teamwork (Kaplan, 1993:19). Efforts to empower existing civil servants are still not conducive to government organizations in the region which are a forum and process of cooperation to interact between available resources and demands systematic utilization of administrative components and personnel management (Pamudji, 1993:24). This concept contains substantial content which is vital, if the direction of the view is aimed at the existence of the area with the development of the scope of activities that are more strategic, even more so with the autonomy policy that has been undertaken Karimun District Government of Riau Islands Province which most of the number and type of autonomy affairs are in the district / to be arranged and administered as a household. These conditions indicate that the Regional Government of Karimun Regency of Riau Islands Province in facing such condition, both present and future struggle to try to organize the government based on the principle of decentralization only or regional autonomy which is accompanied by increasing the quality of human resources Civil Servants (PNS) in the area.

\section{Method}

This research is using qualitative paradigm with inductive approach. Data collecting technique is using qualitative method namely interview, documentation and observation. The data is analyzed by qualitative technique with data reduction, data display, and conclusion.

\section{Resource Quality of Government Apparatus of Karimun Regency of Riau Islands Province}

\subsection{Knowledge Dimensions}

Changes in employee attitudes and the nature of work should be a change towards knowledge-based work that requires knowledgeable workers as well, as simplicity and work routines have shifted towards innovative, multi-skilled work and teamwork. Kasim (1998:23) says that "Efforts to empower existing civil servants are still not conducive to government organizations in the region which are a forum and process of cooperation to interact between available resources and demands systematic utilization of administrative components and personnel management". This concept contains vital substantial content, if the direction of the view is aimed at the existence of the area with the development of the scope of activities that are more strategic, especially with the policy emphasizing autonomy in the district / city which most of the number and type of autonomy affairs are in the district/city to be organized and administered as a household. This condition indicates that the Government of Karimun Regency of Riau Islands Province in facing this condition, both present and future struggle to try to organize the government based on the principle of decentralization only or regional autonomy which is accompanied by increasing the human resources of Civil Servants) in Karimun District Government of Riau Islands Province.

Government employees of Karimun Regency Riau Islands Province have the ability (ability) 
stored (potential) to develop himself, knowledge (knowledge) and skills (skills) to change something in order to have added value. Barry (1994:22) says that "Human resources as a potential employee of Karimun Regency Government of Riau Islands Province that can be developed for process and result productive". This condition indicates that the potential of Karimun District Government of Riau Islands Province cannot be determined its limits, but knowledge (skills), skill (skills) and ability (ability) of a person can be measured according to the provisions of a position or occupation. That is why, the employees of Karimun Regency Government of Riau Islands Province within the organization are grouped into work units to make it easier to manage or called human resource management (Human Resources Management) which is the process of utilizing the employee of Karimun Regency Government of Riau Islands Province as humane workforce, so that their physical and psychological potentials are functioning optimally for the achievement of organizational goals of Karimun Regency Government of Riau Islands Province.

The objective of the management of staff resources of Karimun Regency Government of Riau Islands Province is to improve the productive contribution of people to the organization in a way that is strategical, ethically, and socially responsible (Davis, 1996:14). Thus, the purpose of utilizing the resources of the Government employee of Karimun Regency of Riau Islands Province is "to increase its contribution so that it brings the results for the organization", but in reality, this has not been done by Karimun Regency Government of Riau Islands Province. It shows that the employees of Karimun Regency Government of Riau Islands Province have not used all human resources properly.

\subsection{Skill Dimension}

Human resource planning should be able to make an inventory of employee skill of Karimun Regency Government of Riau Islands Province, apart from inventory of existing personnel, existing employee qualification, length of service, knowledge of employee, talents that still need to be developed, employee interest, especially those relating to activities outside of its current job duties. The results of these investigations, in order to utilize the resources of the Government employee of Karimun Regency of Riau Islands Province in carrying out the current tasks, but for at least four interests of Karimun Regency Government of Riau Islands Province in the future are: promotion, improvement of task ability, mutation with the same nature and position as before, mutations with different task and position properties but the same echelon and hierarchy. Through careful human resource planning, the work productivity of existing personnel can be improved (Edwin, 1995:15). This can be realized through certain adjustments, such as skills improvement so that every employee of Karimun Regency Government of Riau Islands Province produces something that directly relates to the interests of the organization.

Kasim (2008:33) says "Employee development includes both training to improve skills in carrying out specific work and education to improve general knowledge and understanding of the overall environment". The development that can be undertaken by Karimun Regency Government of Riau Islands Province is training to improve skills and knowledge to do certain work, and education related to the improvement of knowledge, understanding, and 
background of Karimun Regency Government officials of Riau Islands Province. Gibson (1998:41) "The process of education is essentially a process of empowerment, which is a process to reveal the potential that existed in Karimun Regency Government employees of Riau Islands Province as individuals, which in turn can contribute to the local community culture to the people of Karimun Regency Riau Islands Province". Improvement of intellectual ability including mastery, application, and development of science and technology so that the mastery can improve the quality of life of Karimun Regency Government officials of Riau Islands Province. Furthermore, Karimun Regency Government officials of Riau Islands Province with the high quality of intellectual ability is a high competitiveness in the middle of global life. Employee development has a wide range of meaning. But in general, the development of employees can be done Karimun District Government of Riau Islands Province as a process of manipulating the work behavior of employees in such a way that employees can show optimal performance in their work. The employee development process undertaken by Karimun Regency Government of Riau Islands Province must be through a systematic planning, implementation, and evaluation process to achieve the development goals of Karimun District Government of Riau Islands Province itself (Suradinata, 1998:31).

\subsection{Abilities Dimensions}

The implementation of governance in Karimun Regency Riau Islands Province based on the principle of decentralization or regional autonomy that continues to improve the ability of human resources of Karimun District Government of Riau Islands Province. This requires the ability of civil servants or human resources available in the government of Karimun District to implement the series of development programs contained in the Regional Mid Term Development Plan of Karimun Regency. According to Dessler (2003:51) says "The quality of human resources at this time is known that the state of growth of Government of Karimun Regency Government since 2013 until 2015 experiencing of minus growth". This is in accordance with central government policy that reduces the number of civil servants in line with the reduction of budget allocation personnel expenditures, especially the reduction of staff formation in administrative positions. As it is known that the allocation of personnel expenditure in almost every local government, especially the regency/municipality government in Riau Islands Province is on average above $50 \%$ of the total allocation of local government budget available. The development of Civil Servants in Karimun District Government for Doctoral Education qualification did not increase significantly from year to year, while the qualification of Magister (S2) education increased significantly by $2.10 \%$, meaning that the Regional Personnel Board of Karimun Regency hopes that in the next five years the State Civil Apparatus in Karimun District Government will be able to increase the knowledge, skill, and skills which in turn will improve the ability and professionalism in the implementation of governmental and development tasks. However, at the level of education with senior secondary education level has decreased significantly around $1.13 \%$, therefore the Regional Staffing Agency of Karimun Regency in performing its duties and functions, starting from recruitment CPNS, distribution, and mutation of employees from outside the Government of Karimun Regency who enter the Government of Karimun Regency should consider the level of education, especially at the level of education Bachelor (S1) in 
accordance with the needs. Simamora (2000:12) says "The quality and capability of human resources of Karimun Regency Government still face problems related to the implementation of regional autonomy". Thus, the quality and ability of human resources become things that need to be improved again. In addition, the environment in Karimun District of Riau Islands Province demands competent ability, but Karimun Regency Government's human resources still can not fulfill it. Abilities of Karimun Regency Government officials of Riau Islands Province can be seen from the ability to mobilize organizations government through charisma and rhetoric, and how the ability of government officials Karimun District Riau Islands Province in creating and feel the decisions that effect. In addition, it also hinted how the ability of government officials Karimun District Riau Islands Province mastermind subordinates and set the play that should be owned by the Government of Karimun Regency Riau Islands Province. Therefore, it can be understood if the abilities of the employee of Karimun Regency Government of Riau Islands Province essentially prioritize the aspect of usage in practice, that is in terms of the relationship between the ruler (ruler) and the ruled (people) (Ndraha, 1997:44). Karimun Regency Government of Riau Islands Province must be able to run the process of government management activities conducted by the ruler or government officials in order to achieve the predetermined objectives, namely improving the welfare of the community in Karimun Regency Riau Islands Province. The effort implements abilities (employees) Government of Karimun District Riau Islands Province above, it is clear that the need for effective, efficient and professional management. This is where the Government of Karimun Regency of Riau Islands Province must be able to answer the various needs. Karimun Regency Government of Riau Islands Province must be able to run the process of government management activities conducted by the authorities or government officials in order to achieve the predetermined objective of improving the welfare of the people in Karimun Regency, Riau Islands Province. Karimun Regency Government of Riau Islands Province has been able to achieve the success of the government in performing its duties, functions, and roles are strongly influenced by the abilities of Karimun Regency Government officials Riau Islands Province is reliable and professional. Karimun Regency Government of Riau Islands Province must be able to maintain some things that have been achieved well, namely: 1) In the existing employment regulation in Karimun District Government of Riau Islands Province has given the clear division of duties; 2) Implementation of existing employment regulation in the Government of Karimun District Province Riau Islands are supported by good leadership type; 3) Leadership style so far supports existing employment regulation in Karimun District Government of Riau Islands Province; 4) Employment regulation existed in Karimun Regency Government of Riau Islands Province in line with cultivated value; 5) Quality of apparatus resources at Karimun Regency Government of Riau Islands Province supported by good employee mind; 6) Quality of apparatus resource at Karimun Regency Government of Riau Islands Province supported by execution of duty by officer; 7) Specialization of an employee in a certain field have become $\mathrm{p}$ affects the quality of apparatus resources at the Karimun District Government of Riau Islands Province; 8) The loyalty of the employees has been proven as the quality of apparatus resources at the Government of Karimun Regency of Riau Islands Province; 9) Cooperation of the employees goes well as evidence of the quality of apparatus resources at 
the Government of Karimun Regency Riau. Several things that are challenges that must be faced by the Government of Karimun District of Riau Islands Province in carrying out the process of government management activities to achieve the goal of improving the welfare of the community in Karimun Regency Riau Islands Province. Thus, the Government of Karimun Regency of Riau Islands Province should be able to improve again some things that have not been achieved properly, namely: 1) Employment regulation in Karimun District Government of Riau Islands Province has not produced the expected employee attitude; 2) Employment regulation in Karimun Regency Government Riau Islands Province has not raised positive employee behavior; 3) Employment regulation in Karimun District Government of Riau Islands Province has not been realized with career planning; 4) Employee development has not been seen clearly in employment regulation exist in Karimun Regency Government of Riau Islands Province; 5) Selection the position has not been conducted with an objective in the existing Employment Regulation in Karimun District Government of Riau Islands Province; 6) Employment regulation exist in Karimun Regency Government of Riau Islands Province not yet supported by the existence of open information; 7) Regulation of staffing is existing in the Government of Karimun District of Riau Islands Province has not been implemented in two-way communication between the leadership and subordinates; 8) Employment regulation existing in Karimun District Government of Riau Islands Province has not received any feedback; 9) Awarding to outstanding employees has not been regulated in the employment regulation which is in the Government of Karimun District of Riau Islands Province; 10) Complaint submission has not been regulated in the existing employment regulation in Karimun District Government of Riau Islands Province. Employment regulation exist in Karimun Regency Government has not made follow-up complaints; 11) The quality of apparatus resources at Karimun District Government of Riau Islands Province has not been supported by adequate employee education; 12) Staffing intelligence has not played a role in the quality of apparatus resources at Karimun Regency Government of Riau Islands Province; 13) Quality of apparatus resources in Karimun Regency Government of Riau Islands Province has not supported by mastering of knowledge by officer; 14) Quality of apparatus resource at Karimun Regency Government of Riau Islands Province not yet supported by operational technical mastery by officer; 15) Training which followed by an employee not build quality of resource apparatus at Karimun District Government of Riau Islands Province; 16) The discipline of the employees has not materialized in the quality of apparatus resources at the Government of Karimun Regency of Riau Islands Province. The responsibility of the employees has not been preserved as a form of the quality of the apparatus resource there is Government of Karimun Regency of Riau Islands Province.

\section{Closing}

The quality of apparatus resources at Karimun District Government of Riau Islands Province is supported by good employee mind and execution of duties by employees. Specialization of employees in a particular field has become an amplifier of the quality of apparatus resources at the Government of Karimun District of Riau Islands Province. The loyalty of employees has been proven as a quality apparatus resources at the Government of Karimun District of 


\section{Macrothink}

Journal of Public Administration and Governance

ISSN 2161-7104

2018, Vol. 8, No. 3

Riau Islands Province. The cooperation of the employees works well as evidence of the quality of apparatus resources at the Karimun District Government of Riau Islands Province.

Dimensions Abilities is the most dominant dimension to form the Quality of Apparatus Resources. Thus the Government of Karimun Regency Riau Islands Province has had employees who have good Abilities, thus giving the largest contribution to the Quality of Resources Apparatus. Skill Dimension is the most inferior dimension of constructing Variable Quality of Resource Apparatus. Thus the Skill of employees in the Government of Karimun District of Riau Islands Province is still very weak, thus giving the smallest contribution to the Quality of Apparatus Resources.

Karimun Regency of Riau Islands Province in carrying out the process of government management activity in reaching its goal must be able to improve existing employment regulation sector by generating attitude and behavior of employee expected and supported by the existence of open information.

Quality of apparatus resources at Local Government of Karimun Province Riau Islands should be supported by adequate employee education and supported by operational technical mastery by the employees.

Training followed by employees should be manifested in building the quality of apparatus resources and have discipline so that the realization of the quality of apparatus resources at the Regional Government of Karimun Regency Riau Islands Province

\section{Glossary}

CPNS: Civil Servant Candidate

\section{Reference}

Barry, C. (1994). Manajemen Sumber Daya Manusia, Jakarta: Elexmedia Komputindo (Terjemahan)

Davis dan Newstrom, (1996). Perilaku Organisasi. Jakarta: Erlangga (Terjemahan)

Dessler, G. (2003). Manajemen Sumber Daya Manusia Jilid 1 Edisi 10, Jakarta: Penerbit PT. Indeks.

Edwin, B. F. (1995). Manajemen Personalia Edisi Ke 6, Jakarta: PT. Erlangga.

Gibson, D. (1998). Organisasi dan Manajemen, Edisi Keempat, Jakarta: Erlangga.

Henry, S. (1995). Manajemen Sumber Daya Manusia, STIE YPKN.

Kasim, A. (1998). Reformasi Administrasi Negara Sebagai Prasyarat Upaya Peningkatan Daya Saing Nasional. FISIP UI.

Kasim, A. (2008). Peluang dan Tantangan dalam Pembangunan Indonesia: Permasalahan dan Upaya Mengatasinya. JIANA, 8(2) (Juli).

Ndara. (1997). Budaya Organisasi, Jakarta: PT Rineka Cipta. 
Pamudji. (1993). Kepemimpinan Pemerintahan di Indonesia. Jakarta: Bumi Aksara.

Peter, F. D. (1954). The Practice Of Management. New York: Happen dan Row.

Riorini, S. vandayuli, (2004). Quality Performance dan Komitmen Organisasi, Jurnal MediaRiset Bisnis dan Manajemen, 4(3), 253-274.

Robert, M., Kaplan, dan D., Saccuzzo, P. (1993). Phsycological Testing principles, application, and issues; Brooks/Cole Publishing Company, Pacific Grove, California, p. 126

Sondang, P. S. (1997). Organisasi Kepemimpinan dan Perilaku Administrasi, Jakarta: PT. Gunung Agung.

Suradinata, E. (1998). Manajemen Pemerintahan dan Otonomi Daerah, Bandung: CV. Ramadan

\section{Copyright Disclaimer}

Copyright for this article is retained by the author(s), with first publication rights granted to the journal.

This is an open-access article distributed under the terms and conditions of the Creative Commons Attribution license (http://creativecommons.org/licenses/by/4.0/). 